\title{
MAPPING THE GRASSROOTS: NGO FORMALISATION IN OAXACA, MEXICO
}

\author{
SARAH MOORE ${ }^{1 *}$, JAMIE WINDERS ${ }^{2}$, OLIVER FRÖHLING ${ }^{3}$, \\ JOHN PAUL JONES, $\mathrm{III}^{4}$ and SUSAN M. ROBERTS ${ }^{5}$ \\ ${ }^{1}$ Center for Latin American Studies, University of Arizona, Tucson, USA \\ ${ }^{2}$ Department of Geography, Syracuse University, Syracuse, USA \\ ${ }^{3}$ Centro de Encuentros y Diálogos Interculturales, Oaxaca de Juárez, México \\ ${ }^{4}$ Department of Geography and Regional Development, University of Arizona, Tucson, USA \\ ${ }^{5}$ Department of Geography, University of Kentucky, Lexington, USA
}

\begin{abstract}
Using data compiled from two surveys of non-governmental organisations (NGOs) in the state of Oaxaca in southern Mexico, we analysed regional variations in the degree of 'formalisation' among NGOs operating in the state. Formalisation is shown to vary from regions with a weak grassroots sector but a top-heavy concentration of activities undertaken by more formalised NGOs, to those with a strong grassroots base but a smaller number of more formalised organisations. These structures do not appear to correlate with either levels of poverty or proportion of indigenous population, but instead with unique geo-historical conditions in each region. We conclude by reflecting on the broader implications of these structures, particularly in the context of neoliberal state policies. Copyright (C) 2006 John Wiley \& Sons, Ltd.
\end{abstract}

Keywords: NGOs; grassroots; civil society; capacity; formalisation; Oaxaca; Mexico

\section{INTRODUCTION}

Macro-scale studies of non-governmental organisations (NGOs) estimate that more than 37000 NGOs are working across national borders, while millions more are operating within individual countries (The Economist, 2000; United Nations Development Programme (UNDP), 2002; Union of International Associations (UIA), 2003/4). The presence and activities of international NGOs (INGOs) are by no means easy to map, but even less is known about the geographic patterns of subnational NGOs and their activities. Within the vast literature on NGOs, there are literally thousands of case studies of

*Correspondence to: Dr S. Moore, Center for Latin American Studies, University of Arizona, Tucson, AZ 85721, USA. E-mail: samoore@email.arizona.edu 
sub-national organisations (e.g. Fernando and Heston, 1997; Crewe and Harrison, 1999; Mawdsley et al., 2002), as a case-study approach is the norm rather than exception in NGO studies (Bebbington, 2004). ${ }^{1}$ Such works provide in-depth, often single-organisation accounts of: NGO structure, history, operation and organisational culture; NGO relations to state institutions, business enterprises, local communities and other civil-society organisations; and NGO effectiveness in on-the-ground projects. The uneven geographies of NGO activity at the sub-national level, however, have yet to be systematically examined in these literatures. In contrast to most studies, therefore, this paper directs attention toward a more extensive (Sayer, 1992) account of the nature and activities of subnational NGOs. Using data compiled from two directories of NGOs in Oaxaca, Mexico, we offer a snapshot of a dynamic and diverse NGO sector in this southern Mexican state, paying particular attention to regional variations.

Our analyses focus on a key characteristic of NGOs - what we call 'formalisation'. We take formalisation to be a construct that places NGOs along a continuum from the most professionalised, largest, oldest, highest capacity and farthest-reaching organisations to the most 'grassroots' - which are likely be more informal, smaller, newer and have fewer resources that are more locally targeted. This continuum may be an important quality in determining an NGO's ability to carry out projects of social development and environmental sustainability. It also provides clues to NGOs' capacities to marshal resources and affect change. The extent of formalisation, for example, can underwrite an organisation's linkages with other NGOs at the local, national and international scale. In doing so, it can affect an NGO's ability to 'scale up' its work and can impact the extent to which an organisation can take advantage of scale economies, technological advances and the latest management trends. Degrees of formalisation may also impact an organisation's ability to serve as an 'implementer', 'catalyst' or 'partner' in community change (see Lewis, 2001, Chapter 3). The concept, however, is not a normative one that connotes better or more effective NGOs. Older, larger and more established organisations may appear to have greater levels of capacity; but the human and social capital an NGO embeds and draws upon can become overly managerialised and bureaucratised, making the organisation cumbersome, politically cautious and slower to respond to opportunities (Josiah, 2001; Roberts et al., 2005). Along the same lines, a smaller, less-established NGO may lack the political visibility to make strong claims on state resources, but may be particularly effective at instituting its desired changes by ‘jumping scales' or creating new networks altogether (Centro de Encuentros y Diálogos Interculturales (CEDI), 2001). Our analysis, therefore, demonstrates the need to consider structures of formalisation within the historical geographies of the sites under examination, rather than to make specific recommendations from the index itself.

The data sources used in this paper enable us to create an index of NGO formalisation based on types of NGOs, their length of operation, their status as legally incorporated entities, their location within Oaxaca and the spatial extent of their operations. Stratified by region, the index allows us to summarise degrees and structures of formalisation as they vary across the state. Although the index-with 'grassroots' NGOs at one end of the continuum and the most formalised at the other-is not uncontestable because of data restrictions and definitional ambiguities, it does capture the sort of distributional differences that allow us to pose key questions drawn from our empirical work in Oaxaca: namely,

\footnotetext{
${ }^{1}$ Examples can be found in the pages of this journal, as well as in Development in Practice, Journal of Development Studies, Third World Quarterly and Nonprofit and Voluntary Sector Quarterly, among others.
} 
how and to what extent does formalisation vary across the state, and what are the causes and potential effects of that variation?

\section{OAXACAN NGOS: CONTEXT, DATA SOURCES, VARIABLES}

The state of Oaxaca in southern Mexico (population 3.5 million) ranks as the second poorest in the country (Clarke, 2000). Growing rural poverty rates have led to major flows of migration to the state capital and north to Mexico City, and increasingly, to the United States (Bustamante, 1999). While oaxaqueños from rural and urban areas have moved out of the region, often in search of employment, a smaller but significant stream of tourists, academics and NGO professionals have come to Oaxaca City. With its quaint colonial architecture, relatively well-developed social infrastructure and congenial urbanity, Oaxaca's capital has become headquarters for an increasing number of NGOs whose activities spread across the poorer regions of the state. The city offers NGO personnel a location 45 minutes by plane from Mexico City, as well as access to information infrastructures, such as reliable E-mail service, an educated population and state and federal agency headquarters. For these reasons, Oaxaca City has become a prime location for international and national NGOs in the state. At the same time that these large NGOs have established a presence in the city, the state itself has witnessed an explosion of smaller NGOs that began in the mid-1980s and continued through the 1990s (see Figure 1). The range of services, training and assistance offered by these groups has rapidly grown in number and in kind.

By the mid 1990s, efforts to document the size and diversity of NGO activities in Oaxaca were underway. These initiatives, sponsored by two Oaxacan NGOs, form the empirical basis of this analysis. Their production and background merits discussion here. In 2000, El Foro de Organismos Civiles de Oaxaca (FOCO) — an umbrella civilsociety organisation funded by the large and successful NGO, Fundación Comunitaria Oaxaca (FCO)_ published Directorio de Organismos Civiles del Estado de Oaxaca. A

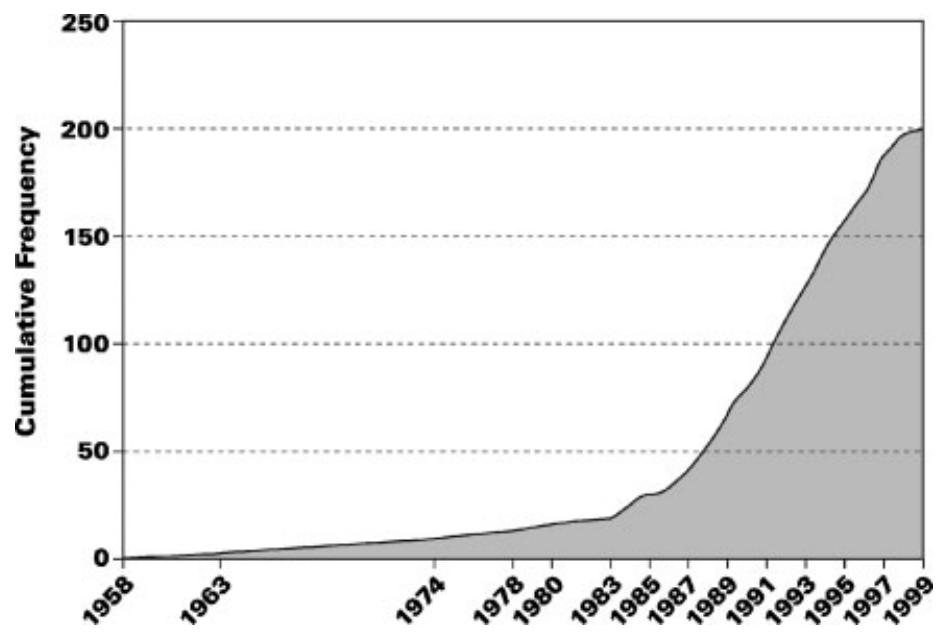

Figure 1. Growth in the number of Oaxacan NGOs. Source: compiled by authors from FOCO directory 
year later, the smaller El Centro de Encuentros y Diálogos Interculturales (CEDI) received funding from Oxfam America to publish its own directory of Oaxaca's NGOs. These two directories together contain information on some 300 NGOs active in Oaxaca in 2000. Our merging of the directories is the most comprehensive and up-todate compilation of NGO activity in Oaxaca. Integrating these documents into one dataset, however, was not a straightforward process, as the two groups took different definitional and methodological approaches to collect their information. We discuss these differences below, before turning to how we combined these data into one comprehensive source and what limitations this combination produced.

Founded by 40 Oaxaca-based NGOs in 1996, FOCO's mission is to safeguard the interests and autonomy of Oaxacan NGOs from the state government's efforts to curtail such civil society ${ }^{2}$ organisations, especially in the mid 1990s. The ruling party, the Partido Revolucionario Institucional (PRI), frightened that NGOs would undermine the state's political control and clientelist system, had, since the late 1980s, participated in the institutionalisation of social action enabled by Salinas de Gortari's Programa Nacional de Solidaridad (PRONASOL). This program was part of Salinas's efforts at what he called 'national modernisation'. Government support for and funding of local social and economic development projects were to be cycled through PRONASOL. While, in some cases, this did provide more groups with funding for such things as local roads, it also resulted in the federal government's having a large, institutionalised role in local social action. This particular program was rolled into the Secretaría de Desarrollo Social (SEDESOL) and upgraded to cabinet status in 1992, highlighting its importance to the federal government. This changed somewhat under the next administration, that of Ernesto Zedillo (PRI, 1994-2000). Like many government programs, the management of PRONASOL devolved to state and local entities during this period, resulting in more state and municipal involvement in social programs.

The NGOs that produced the directories used in this study sought to influence this state involvement by directing attention to Oaxaca's active NGO sector. In particular, FOCO's founding members hoped to streamline NGO activities in Oaxaca and enhance both NGO visibility within the state and the depth of their programs and activities across it. For their directory, FOCO sought groups that focused on Oaxaca's profound social, economic, environmental and cultural changes (Foro de Organismos Civiles de Oaxaca (FOCO), 2000, p. vii). They prioritised groups engaged in challenging poverty, exclusion, human-rights violations and environmental destruction and, through their selection process, exhibited a preference for organisations that were legally constituted and/or had a long history of involvement in Oaxacan civil society. Although FOCO collected data on organisations falling outside these designations, new groups that lacked legal constitutions were not specifically targeted. Of the 318 groups contacted by FOCO, $209(66 \%)$ responded with information included in the directory (Foro de Organismos Civiles de Oaxaca (FOCO), 2000, p. x).

The FOCO directory was not designed as a comprehensive census of all civil-society organisations in Oaxaca but, instead, was meant to initiate conversations about current and future trends in Oaxacan civil society, including the NGO sector. That conversation continued a year later, when CEDI published its own directory that included 173 NGOs,

\footnotetext{
${ }^{2}$ We see civil society as a broader category of social interactions that includes NGOs. In this paper, we are concerned with analysing the NGO sector specifically.
} 
83 of which were not in the FOCO study. In contrast to FOCO's broad definition of Oaxacan civil society, CEDI focused on groups composed of or serving los pueblos indigenas (indigenous peoples) as the 'most extensive and dynamic component of civil society' (Centro de Encuentros y Diálogos Interculturales (CEDI), 2001, p. 7). Thus, while FOCO's directory emphasised larger and more established NGOs found in urban settings, CEDI's database focused on newer, smaller organisations located in the state's myriad indigenous communities.

In addition to their different entry points into and understandings of Oaxacan NGOs, the two organisations employed different approaches to gather information. Organisations contacted by FOCO were asked to complete a written questionnaire covering areas such as general organisation information, institutional profile, areas and populations served and inter-organisational networks. This information was typically obtained through personal contact, although some surveys were submitted by fax or mail. The FOCO survey provided a list of options for each question, such that participating organisations classified the areas in which they worked by geographical region and the services they provided by broad, predetermined themes (Foro de Organismos Civiles de Oaxaca (FOCO), 2000). In this way, some details about the actual types of services offered and specificities about the actual location of NGO activities were not captured.

By contrast, CEDI sent a team of interviewers across Oaxaca to conduct open-ended interviews with NGO leaders. These interviews were loosely organised and typically traced each organisation's formal and informal history, its most prominent activities, current needs and issues and future plans. Through this approach, CEDI collected a great deal of textured information for each organisation (Centro de Encuentros y Diálogos Interculturales (CEDI), 2001, p. 7), but in a non-systematic way. Since each interviewer asked somewhat different questions or initiated conversations in different ways, the material discussed in each interview, and the subsequent description of each group, was not uniform. Whereas FOCO's directory provided a short, thematically organised discussion of each organisation, CEDI's directory described each group in one- to four-page narratives that often included in-depth discussions of group philosophies and internal mechanics.

Differences between the two data sources required multiple decisions about data comparability, and we evaluated each NGO in terms of a number of variables. Privileging, in cases of common inclusion, the more detailed information found in the CEDI directory led us to include 173 of their organisations, some of which were also listed in the FOCO directory and 119 groups listed only in the FOCO directory. This combination generated a total number of 292 NGOs. ${ }^{3}$ Deviations from this number in the following analyses reflect missing information for one or another variable. After integrating the two directories, we were left with more than 40 variables that measured spatial extent, population sectors served, services offered, age, legal status and NGO type, among other attributes. Here, we focus on five variables - the type of NGO, its legal status, whether or not it has its headquarters in Oaxaca City, the spatial extent of its operations and its age — and assess the regional dimensions of these variables. Below, we discuss these variables in turn.

NGO TYPE: In collating the FOCO and CEDI data, we distinguished between three types of NGOs, each associated with a degree of formalisation. We counted 100 (34\% of a

\footnotetext{
${ }^{3}$ We believe the actual number of active NGOs in Oaxaca may reach 400 . Thus, the sample we collected from the two directories is not exhaustive. Nonetheless, our on-going involvement in Oaxaca, as both researchers and NGO members, leads us to conclude that our sample of approximately 300 NGOs is representative of the spectrum of such organisations currently in existence in the state.
} 
total of 292) place-based organisations that focused on one particular locality in Oaxaca and the concerns or issues of people in that place. San Pedro Ayacaxtepec A.C., for example, is a place-based NGO that works exclusively within the pueblo of the same name and promotes the interests of coffee growers there. We also found 149 (51\% of the total) roving organisations that work in a particular sector and respond to needs and opportunities in that thematic area, rather than in a specific location. Niño a Niño, A.C., for example, works with children in marginalised, often indigenous, areas throughout Oaxaca and is, thus, a roving NGO. Finally, we identified 43 (15\% of the total) dependent NGOs that were branches or subsidiaries of other nationally or internationally active organisations. Liga Mexicana por la Defensa de los Derechos Humanos A.C., an offshoot of a national human-rights organisation based in Mexico City, is one example. In terms of this variable, we would expect that place-based organisations will be least 'formalised', while those organisations with dependencies upon national and international organisations will, by virtue of these associations, be most 'formalised'. Roving organisations, which address social and environmental problems in multiple areas but lack formal dependencies upon the national and INGO sector, are expected to fall in the middle.

LEGAL STATUS: This variable distinguishes between organisations that have a legal constitution and those that do not. In order to be a legally constituted NGO in Mexico, a group must write a formal document outlining its membership, structure, mission, purpose and procedures. ${ }^{4}$ This document must be signed by a notary public and registered with hacienda, the Mexican taxation authority. Because this process is fairly costly and time consuming, many groups, especially small organisations, often wait to go through the process until they have an incentive, such as potential financial assistance from foundations or government agencies that require them to be legally registered. Being legally constituted is, thus, a key indicator of a group's degree of formalisation, as legalisation also implies keeping financial records and paying taxes. Of the 276 cases in our data compilation, $219(79 \%)$ were legally constituted.

CENTRAL LOCATION: This binary variable indicates whether the location of NGO headquarters is in or outside of Oaxaca City, Oaxaca's primary city politically and economically. Although many influential and effective NGOs, as well as scores of grassroots organisations, are found outside the capital, groups seeking or requiring international linkages to conduct their work are significantly advantaged by a location in the state's largest city (population approx. 750000 ). Of the 292 NGOs in our database, $122(42 \%)$ were headquartered in Oaxaca City.

OPERATIONAL SPACE: This five-category variable was produced by either summarising eight spatial categories of operation, from intra-community to international, from the CEDI directory or by qualitatively assessing spheres of activity reported in the FOCO directory. The resulting categories of operational space are: (a) community, including intra-community and community-wide operations, which accounts for 51 of the 292 NGOs (18\%); (b) municipal, including municipality-wide and multi-municipality groups, accounting for 56 organisations (19\%); (c) regional, including NGOs that work throughout one Oaxacan region, comprising 84 NGOs (29\%); (d) statewide, including NGOs working in multiple regions or across the state itself, comprising 80 NGOs (27\%) and (e) supra-state, including NGOs with either a dependency on a non-Oaxaca-based NGO (e.g. subsidiaries of Mexican national NGOs or INGOs) or a presence in more than

\footnotetext{
${ }^{4}$ This process, which required a considerable amount of effort during the time period when these organisations were founded, has become even more cumbersome under the current government.
} 
one Mexican state. There were 21 such NGOs in the compiled database (7\%). In contributing variation to our measure of formalisation described below, we anticipate that as operational reach increases, the index will increase.

YEAR BEGAN: Our final measure of NGO formalisation is the year in which the organisation began its work. ${ }^{5}$ For the CEDI data, this information was pulled from narrative accounts of each NGO's history, while for the FOCO groups, the information was requested in the survey instrument itself. The average founding date for the NGOs in our data set was 1991, with a standard deviation of 7.2 years. While the data cannot capture change over time, it is clear from Figure 1 that NGO presence accelerated in Oaxaca during the 1990s. This trend both parallels the expansion of Mexican NGOs throughout the decade and represents a series of responses to the specific conditions in the state of Oaxaca (Morales Rodríguez, 1996). The shift from the previously slow-but-steady slope around 1985-88, for example, confirms the rapid growth of NGOs in Oaxaca at roughly the onset of Mexico's economic crises and the state's withdrawal from many economic and social spheres (Aguayo Quezada, 1995; Barkin, 1998; Cockcroft, 1998). ${ }^{6}$

\section{ANALYSES BY REGION}

\subsection{Locating NGOs}

Oaxaca has eight officially recognised regions (Figure 2), though in several cases, the social and environmental diversity they encapsulate suggest the need for additional spatial divisions. ${ }^{7}$ The Valles Centrales is the most heavily populated region of the state. In addition to Oaxaca City, it contains a large number of smaller communities that are increasingly drawn into the capital's urban sphere even while they function as secondary administrative and market centres. Several of the regions are extremely mountainous, with Cañada, Sierra Norte, Sierra Sur and Mixteca having particularly rugged terrain. These mountain regions tend to be predominantly agrarian and indigenous, with indigenous peoples accounting for approximately $80 \%$ of the population in Cañada and Sierra Norte. The Mixteca, one of the richest regions during the 17th century, today has one of the world's most severe soil erosion problems and the highest rate of outmigration in Oaxaca. Outmigration is also prominent in other parts of the state, where the draw of high wages in the United States is exacerbated by declining prices for commodities such as coffee, a main product of the Sierra Sur. The Costa and Istmo are relatively flat regions and have been differently incorporated into the Oaxacan and Mexican political economy. The Costa, for example, exudes an air of wealth centred on a large international tourist development at Huatulco, while the Istmo is an area rich in agricultural, fishery, commercial and industrial resources. Historically, the Istmo's high level of economic independence, coupled with the dominance of Zapotec culture over other indigenous groups, has made it something of its own entity, with loose ties to the administrative centre of Oaxaca City and frequent separatist movements.

\footnotetext{
${ }^{5}$ We also have a variable specifying the date of legal constitution, but employing that measure would leave the $21 \%$ of unincorporated NGOs in our data set with a missing value.

${ }^{6}$ The figure also shows that there were NGOs in Oaxaca much earlier, some of which were in operation as early as the 1940s. Typically, these are branches of larger, often church-related, organisations.

${ }^{7}$ These regions are not based on any particular criterion and do not display internal homogeneity in ethnic, economic, topographic, biological or cultural terms. They have, however, been used by government agencies for planning and policy purposes since the 1930s, and are used by NGOs for planning exercises. They are also well anchored in popular culture through state-sponsored folkloric rituals.
} 


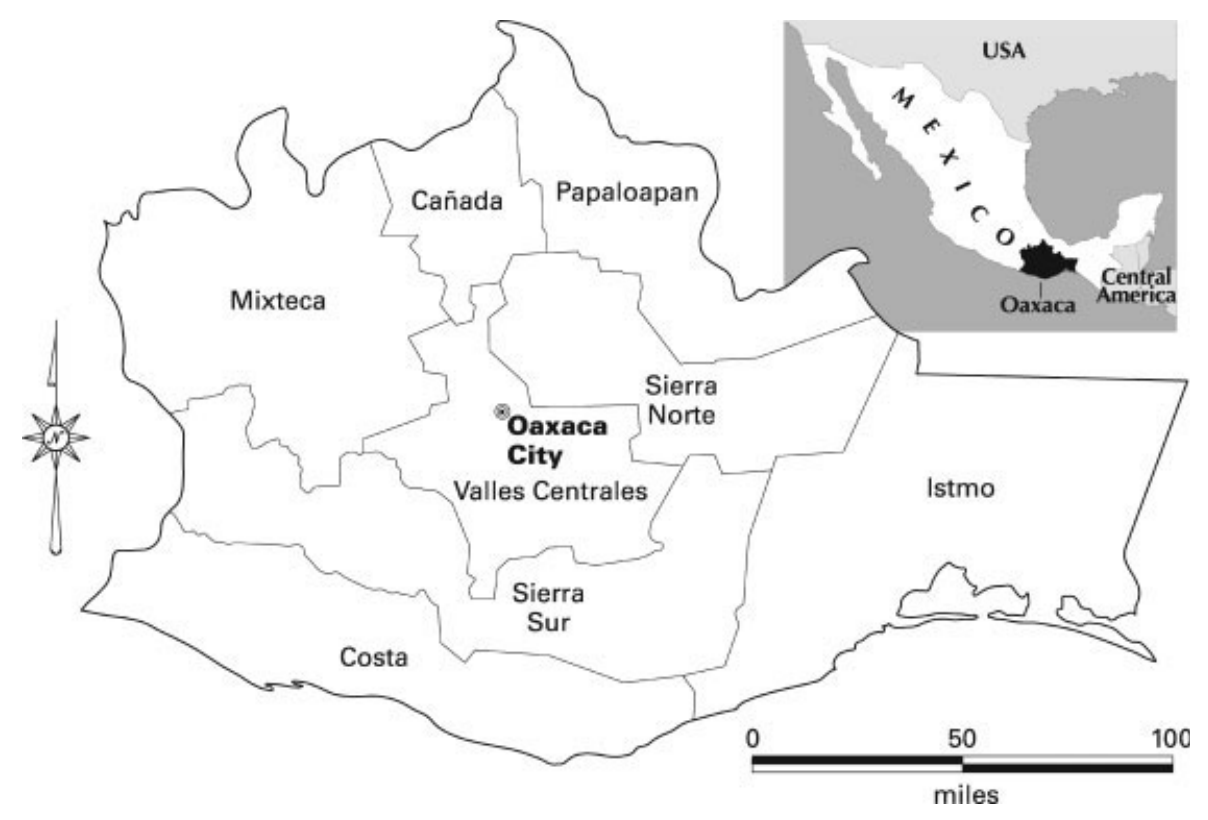

Figure 2. The eight regions of Oaxaca

Table 1 shows regional variation in population, NGO presence, per cent indigenous and per cent of economically active population earning at or less than the official minimum salary (currently around US $\$ 4$ per day). The regions are listed in descending order of this last variable, thereby providing a ranked indication of the levels of poverty across the state. As the table shows, NGO activity is unevenly distributed across Oaxaca, with NGOs more concentrated in the rural, mountainous regions of the two Sierras, the Mixteca and Cañada. Sierra Norte, one of the poorest regions, is well represented in terms of NGO presence, with far more NGOs per capita than any other region. The more urban, and generally better off, Valles Centrales, by contrast, has a lighter NGO presence per capita. Because of the influence of Oaxaca City, however, it has more total NGO activity. The low density of NGOs in Papaloapan is perhaps attributable to its relative proximity to Veracruz. There

Table 1. Regional socio-economic and NGO profile

\begin{tabular}{lccccc}
\hline Region & Population & $\begin{array}{c}\text { Number of } \\
\text { NGOs reporting } \\
\text { activities in region }\end{array}$ & $\begin{array}{c}\text { Population } \\
\text { per NGO } \\
\text { activity }\end{array}$ & $\begin{array}{c}\% \\
\text { Indigenous }\end{array}$ & $\begin{array}{c}\% \\
\text { Earning } \\
\text { minimum }\end{array}$ \\
\hline Cañada & 201937 & 38 & 5314 & 77.9 & 77.4 \\
Sierra Norte & 170861 & 110 & 1553 & 79.7 & 73.3 \\
Sierra Sur & 300396 & 61 & 4925 & 34.5 & 67.4 \\
Mixteca & 430713 & 78 & 5522 & 39.2 & 58.6 \\
Papaloapan & 434278 & 59 & 7361 & 43.3 & 49.7 \\
Costa & 479529 & 83 & 5778 & 34.2 & 47.1 \\
Istmo & 542919 & 80 & 6786 & 34.9 & 41.8 \\
Valles Centrales & 878132 & 120 & 7318 & 19.3 & 31.7 \\
\hline
\end{tabular}

Source: Compiled from FOCO and CEDI directories, with additional data from the Instituto Nacional de Estadística Geografía e Informática (INEGI), 2000 census. 
may be more NGOs active in Papaloapan than our data capture; but these groups are likely more networked into the professional circuits running through Veracruz rather than Oaxaca, reflecting historic and contemporary ties with the adjacent coastal state.

\subsection{Regional Patterns of Formalisation}

Below we evaluate the five measures of NGO formalisation across the regions of Oaxaca. It should be re-emphasised that the regional patterns discussed do not pertain to NGOs with headquarter locations in the regions but rather to NGOs reporting activities within them. Data for Cañada's 38 NGOs, for example, include not only NGOs based in Cañada but also NGOs headquartered elsewhere with projects in the region. This approach provides us with a clearer portrait of the characteristics of NGOs at work in each region. Because many NGOs work in multiple regions, the results are not based on mutually exclusive but on overlapping observations.

The first variable is NGO TYPE, reported by region in Table 2. What stands out is the low proportion of place-based NGOs with activities in the regions of Cañada and Sierra Sur, where only 5 and 7 per cent of NGOs are so identified. As place-based organisations are tied to a single area, the figures indicate a low level of grassroots organisation in these poor regions, in stark contrast to the regions' strong reliance on 'roving' NGOs (82 and 75\%, respectively - the largest proportion of such organisations across the 8 regions). By contrast, the relatively poor region of Sierra Norte has the largest proportion of place-based organisations, indicating a high density of smaller, indigenous organisations - a point to which we return later in this paper. Across the state, there was little regional variation in the presence of dependent organisations, that is, NGOs connected to national or INGOs. The Istmo region has the largest percentage; but even there, nearly four-fifths of all NGOs were either place-based or roving.

Table 3 reports results for LEGAL STATUS, CENTRAL LOCATION and YEAR BEGAN. Regional variability is modest on LEGAL STATUS, with the results ranging from a high of around $90 \%$ for several regions to a low of just under $75 \%$ for the Sierra Norte. This finding is consistent with that reported for Sierra Norte in Table 2, in which the region registered a high proportion of place-based activity. It stands to reason that more place-based organisations would have a lower proportion of legally incorporated groups. Variability, however, is more

Table 2. Regional concentration of activities by NGO TYPE

\begin{tabular}{lccc}
\hline Region & $\begin{array}{c}\text { \% of } \\
\text { activities by } \\
\text { place-based NGOs }\end{array}$ & $\begin{array}{c}\% \text { of } \\
\text { activities by } \\
\text { roving NGOs }\end{array}$ & $\begin{array}{c}\% \text { of } \\
\text { activities by } \\
\text { dependent NGOs }\end{array}$ \\
\hline Cañada & 5 & 82 & 13 \\
Sierra Norte & 34 & 52 & 14 \\
Sierra Sur & 7 & 75 & 18 \\
Mixteca & 17 & 72 & 11 \\
Papaloapan & 15 & 70 & 15 \\
Costa & 13 & 71 & 16 \\
Istmo & 19 & 59 & 22 \\
Valles Centrales & 12 & 72 & 16 \\
\hline
\end{tabular}

Source: Analysis based on data compiled from FOCO and CEDI directories.

Notes: Based on 292 NGOs. 
Table 3. Regional concentration of NGO activities by LEGAL STATUS, CENTRAL LOCATION and YEAR BEGAN

\begin{tabular}{lccc}
\hline Region & $\begin{array}{c}\% \text { of } \\
\text { activities by } \\
\text { NGOs with } \\
\text { legal constitution }\end{array}$ & $\begin{array}{c}\% \text { of } \\
\text { activities by } \\
\text { NGOs with } \\
\text { headquarters in } \\
\text { Oaxaca City }\end{array}$ & $\begin{array}{c}\text { Average founding } \\
\text { year of NGOs } \\
\text { conducting activities }\end{array}$ \\
\hline Cañada & 86 & 82 & 1991 \\
Sierra Norte & 73 & 55 & 1991 \\
Sierra Sur & 88 & 80 & 1992 \\
Mixteca & 88 & 64 & 1990 \\
Papaloapan & 86 & 64 & 1990 \\
Costa & 91 & 62 & 1991 \\
Istmo & 78 & 48 & 1991 \\
Valles Centrales & 89 & 79 & \\
\hline
\end{tabular}

Source: Analysis based on data compiled from FOCO and CEDI directories.

${ }^{1}$ Based on 276 observations.

${ }^{2}$ Based on 292 observations.

${ }^{3}$ Based on 273 observations.

marked for CENTRAL LOCATION. Here, the limited number of active organisations based in Cañada and Sierra Sur again reveals their ties to a more formalised structure, with four-fifths of their organisations headquartered in Oaxaca City, a figure surpassing even that of Valles Centrales. The Istmo and Sierra Norte are the least connected to the state's capital, with around half of their NGOs having such ties. These findings are consistent with those shown in Table 2, as these were regions with high levels of place-based NGOs.

Perhaps YEAR BEGAN provides the most surprising result. We anticipated a diffusion effect of NGO activity across the state, with an older cohort of NGO operations in the Valles Centrales matched, via a demonstration effect, by an increase in recent NGO activities in the more remote regions. Instead, the differences are minor, with average dates of NGO founding among those having activities in the regions varying between 1990 and 1992. In regionally disaggregated time graphs not reported here, these findings have further support. Each of the eight regions shows the familiar S-shaped diffusion curve similar to that shown in overall data in Figure 2, though the points of inflection vary slightly across the regions in accordance with the differences in average founding dates shown in Table 3. This result indicates that NGO activity spread rapidly and evenly throughout the state in the late 1980s, even though the absolute number and population-density of NGOs (see Table 1) still varies greatly by region.

Table 4 shows the regional concentration of NGO activity according to our measure of OPERATIONAL SPACE. Here, the results are more striking and confirm findings in the previous tables. In particular, the data show no NGOs classified in the smallest two categories in Cañada. Similarly, none of the organisations working in Sierra Sur are reported to be community operations, and only 5 per cent operate at the municipal level. Instead, both regions have a large proportion of NGOs with statewide reach, indicating that these regions rely on more far-flung organisations. Meanwhile, in Sierra Norte, a region ranked economically between Cañada and Sierra Sur, the picture is quite different, with much higher concentrations of NGOs operating at the community level. Outside these three regions, the major differences in OPERATIONAL SCALE are found in the proportion of statewide NGOs, particularly between the middle-ranked economic regions (Mixteca, 
Table 4. Regional concentration of NGO activities by OPERATIONAL SPACE

\begin{tabular}{lccccc}
\hline Region & $\begin{array}{c}\% \text { of } \\
\text { activities in } \\
\text { region } \\
\text { undertaken } \\
\text { by community } \\
\text { operating } \\
\text { NGOs }\end{array}$ & $\begin{array}{c}\% \text { of } \\
\text { activities in } \\
\text { region } \\
\text { undertaken } \\
\text { by municipally } \\
\text { operating } \\
\text { NGOs }\end{array}$ & $\begin{array}{c}\% \text { of } \\
\text { activities in } \\
\text { region } \\
\text { undertaken } \\
\text { by regionally } \\
\text { operating } \\
\text { NGOs }\end{array}$ & $\begin{array}{c}\% \text { of } \\
\text { activities in } \\
\text { region } \\
\text { undertaken } \\
\text { bytatewide } \\
\text { operating } \\
\text { NGOs }\end{array}$ & $\begin{array}{c}\text { of } \\
\text { activities in } \\
\text { region } \\
\text { undertaken } \\
\text { by sura-state } \\
\text { operating } \\
\text { NGOs }\end{array}$ \\
\hline Cañada & 0 & 0 & 3 & 87 & 10 \\
Sierra Norte & 19 & 10 & 16 & 44 & 11 \\
Sierra Sur & 0 & 5 & 2 & 82 & 11 \\
Mixteca & 4 & 6 & 13 & 63 & 14 \\
Papaloapan & 3 & 12 & 10 & 63 & 12 \\
Costa & 3 & 10 & 12 & 64 & 11 \\
Istmo & 13 & 17 & 13 & 47 & 10 \\
Valles Centrales & 10 & 7 & 24 & 47 & 12 \\
\hline
\end{tabular}

Source: Analysis based on data compiled from FOCO and CEDI directories.

Notes: Based on 292 NGOs.

Papaloapan and Costa) and the Istmo and Valles Centrales. There was little difference in the regional concentration of supra-state NGOs.

\subsection{An Index of NGO Formalisation}

To summarise our regional analyses of formalisation, we elected to construct a single index composed of variation across the five variables. We conducted a principal components analysis with listwise deletion of missing cases; this resulted in 260 valid observations out of the original 292 NGOs. Only one of these variables is continuous-that of YEAR $B E G A N$. Two were ordinal variables: (a) NGO TYPE was coded 1 for place-based, 2 for roving and 3 for dependent, which can be interpreted as a ranked value indicating the increasingly connected character of the organisations (mean 1.82, S.D. 0.67), while (b) OPERATIONAL SPACE was coded 1 for community, 2 for municipal, 3 for regional, 4 for statewide and 5 for supra-state (mean 2.9, S.D. 1.2). Finally, LEGAL STATUS and CENTRAL LOCATION were treated as binary variables, with zero entries for NGOs without a formal constitution or central headquarters in Oaxaca City.

The principal components analysis employed a varimax rotation to simple structure and resulted in one factor with an eigenvalue greater than 1.0. This indicates that the five variables can indeed be adequately summarised by a single component (which, in this case, captured $38.8 \%$ of the total variation in the data). The correlations (or component loadings) of the original variables to the extracted component are shown in Table 5. The results

Table 5. Component loadings for the five formalisation variables

\begin{tabular}{cccccc}
\hline & NGO & LEGAL & CENTRAL & OPERATIONAL \\
TYPE & STATUS & LOCATION & $\begin{array}{c}\text { YEAR } \\
\text { SPACGAN }\end{array}$ & BEG \\
\hline Component loading & 0.655 & 0.551 & 0.716 & 0.780 & -0.298 \\
\hline
\end{tabular}

Source: Analysis based on data compiled from FOCO and CEDI directories.

Notes: Based on a total number of 260. 
indicate that, of the five variables, all are significantly correlated to the component (the index), with YEAR BEGAN showing marginal (inverse) association and the other variables showing moderate to strong relationships. In general, the index produced from this analysis can be said to identify NGOs that are less spatially constrained, have legal status, are located in Oaxaca City, operate in multiple regions and are older. These features are all consistent with a continuum of formalisation that stretches from, on the one hand, the mostestablished, centrally located and spatially dispersed organisations to, on the other, the least-established, most peripherally located and spatially constrained organisations.

Table 6 shows the mean principal component scores (or formalisation index) for the organisations working in each of the eight regions. The results show that two of the poorest regions, Cañada and Sierra Sur, have the highest levels of formalised NGOs, a finding consistent with the individual variable analyses but more striking in the case of the overall NGO index of formalisation. Why would this be so? First, we note that the formalisation index is not a simple surrogate for either the level of indigeneity or poverty in the regions. A glance down the table's rows, organised from poorest to richest region, shows little apparent trend with the formalisation index. The simple correlations between the index and the indigeneity and poverty variables (shown in Table 1) are -0.12 and 0.20 , respectively. One must look, therefore, to a more complex set of conditions underwriting formalisation based on the culture, history and economy of a particular region. For example, the low level of formalisation and high incidence of grassroots NGOs in Sierra Norte are partially results of community organising to reclaim communal lands and logging rights, effort that began in the 1970s and continued into the 1990s. The resulting forestry programs operate within an environment in which the 'community', measured in terms of adjacent lands, is the strongest aspect of lived identity, much stronger than the more widely dispersed patterns of ethnicity in Sierra Norte. Organisations in this region are, thus, more likely to be local in character. It is also noteworthy that after the struggles over forests were effectively won in the 1990s, many of the resource-based organisations lived on as grassroots NGOs under a more cultural umbrella, a substantive focus that could also be locally based and result in fewer ties to Oaxaca City.

In a similar way, since the formalisation index depends to a large degree on the CENTRAL LOCATION variable, the fact that the Istmo scores low is not surprising. In addition to being a relatively independent region culturally, politically and economically,

Table 6. Formalisation by region

\begin{tabular}{lc}
\hline & Mean index of NGOs with activities in region \\
\hline Cañada & 0.89 \\
Sierra Norte & 0.22 \\
Sierra Sur & 0.85 \\
Mixteca & 0.58 \\
Papaloapan & 0.60 \\
Costa & 0.63 \\
Istmo & 0.28 \\
Valles Centrales & 0.65 \\
\hline
\end{tabular}

NB: Note that the averages are taken by region according to the location of NGO activities, as shown in Table 1. This accounts for the positive values found in all regions, as those NGOs with operations in multiple states tend to have a higher individual index of formalisation.

Source: Analysis based on data compiled from FOCO and CEDI directories.

Notes: Higher values indicate more formalised NGOs operate in the region. Based on a total number of 260 observations. 
the Istmo has been a site of United States' imperial ambitions, and local resistance, since the 19th century. The region's contemporary NGO infrastructure reflects this independence. While the Istmo has fewer NGOs per capita, its organisations tend to network with one another, reflecting the region's geographical pattern of economic and cultural connectivity between villages and urban areas, rather than with Oaxaca City (Centro de Encuentros y Diálogos Interculturales (CEDI), 2001).

On the other end of the spectrum are the Sierra Sur and Cañada, two regions that have long been dominated by extractive activities and export cash-crop production. Cañada, on the main route between Oaxaca, Puebla and Mexico City, has historically been a site of export agriculture, especially tropical fruits, while the main products of Sierra Sur are coffee and wood, with coffee still being produced on large estates. The truncated grassroots NGO sector in both seems to mirror the more centralised and colonialist economy that has developed within these regions. Yet the blame for their dependencies upon formalised NGOs should not be placed solely on the shoulders of local capital. The weaker development of grassroots NGOs in Sierra Sur might also be hampered by widely reported evidence of guerilla organising and drug trafficking in the region. In response to these factors, the government has taken a more repressive stance with respect to civic organising, especially when it involves human rights NGOs.

\section{CONCLUSION}

In summarising its study of civil society in Oaxaca, CEDI reported great heterogeneity across the state (Centro de Encuentros y Diálogos Interculturales (CEDI), 2001, p. 16). Through detailed interviews with leaders of 173 organisations, CEDI concluded that Oaxaca is the site of a growing, dynamic set of social organisations that includes the most formal and wealthy to the smallest and most loosely organised. Our analyses confirm that finding but go further to describe regional differences in the structure of the state's NGO sector. We found variation, not in the timing of NGO activities across the state, but in the level of formalisation of organisations and the overall structure of formalisation in each region. We identified regional variations in levels of NGO activity relative to population and found regions with poorly developed grassroots sectors. We also found regions with a strong base of local organising, but with few larger operations. Other regions had less structural imbalance, demonstrating active levels of organising across our index of formalisation.

A corollary finding is that these structural differences do not follow in step with levels of poverty or with the presence of a large indigenous population. This suggests that variations in NGO structures are the result of complex historical geographies that require different explanations in each place. Put differently, each region has its own path dependency: a mix of socio-cultural, economic, political and environmental forces which, when tied to the idiosyncratic geographies of human agency, produce multiple and intersecting contingencies and a variegated civil-society sector.

The intrinsic value of understanding geographic variation in the structure of formalisation can be illustrated in Figure 3. The figure shows three idealised distributions of NGOs according to a hierarchy that places smaller and less-well-established organisations at the bottom and larger and more-established ones at the top. The distribution of (a) reveals a prevalence of grassroots NGOs. This idealised structure is most reflective of the cases of the Istmo and Sierra Norte, which demonstrate relatively low levels of formalisation. In (c), on the other hand, we find the reverse. This 'top-heavy' 


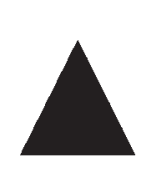

(a)

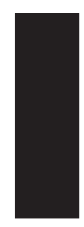

(b)

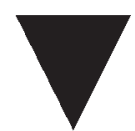

(c)

Figure 3. Ideal types of NGO formalisation: (a) grassroots oriented/less formalised structure; (b) uniform structure; (c) top heavy/more formalised structure

structure is evident in the areas of Cañada and Sierra Sur, where formalisation is most prevalent. The shape of (b) shows a uniform distribution across the hypothetical metric of formalisation. This more balanced structure is evident in the regions of Mixteca, Paploapan, Costa and Valles Centrales. While we should be careful about privileging (b)'s more equal distribution (just as we should be suspicious about romanticising (a)'s grassroots profile), it does seem clear that there are implications for each of the distributions. In (a), there is a strong base, coupled with the absence of established organisations, suggesting that scaling up activities might, for one reason or another, be limited in the area, with correspondingly less capacity to link to wider state and civil society institutions. Conversely, (c)'s top-heavy structure points to a weak grassroots sector and, most likely, to significant spatial gaps in the population's access to NGO services. Such a situation could result from poorly developed social infrastructure, perhaps due to poverty, ethnic conflict or heavy-handed state or capitalist coalitions that suppress local organising. Although (b), with its more uniform distribution, might suggest a healthy sector at every level of formalisation, our intent is not to equate formalisation with effectiveness, efficiency or political persuasion, as that sort of assessment is an empirical question for each NGO. We can, however, project that in regions with distributions such as (b), we will find a greater number of total potential flows of knowledge and resources across a wider diversity of NGOs (Roberts et al., 2005). Insofar as this potential can effectively link NGOs with a larger number of jointly conceived and undertaken development projects, it would seem to be, ceteris paribus, a preferred structure. Although formalisation is but one of many challenges facing those seeking to strengthen the NGO sector (Townsend et al., 2002), our attempts to measure and assess it quantitatively, and to analyse the NGO sector through a geographic lens, offer a potentially useful methodological tool not only for scholars who typically rely on a qualitative case-study approach to NGOs, but also to policymakers who face the task of negotiating the complex and uneven landscape of NGO activity in different geographic contexts.

This result, finally, has implications for those who trust that NGOs can pick up the pieces left behind after the neoliberal rollback (Peck and Tickell, 2002) of the 1980s and 1990s. Specifically, our analyses show that NGOs in Oaxaca are just as unevenly developed as its economy and state institutions ever were (Clarke, 2000). The goal of this paper has been to better understand the basics of that uneven and complex geography and to begin some initial explanations of it. In the future, it will take a concerted effort on the part of the policymakers, funders and development professionals to see that all areas have access to the services that NGOs provide and that they are served by a diversity of organisations with varying capacities - from the most local and grassroots to the most wide-ranging and established. 


\section{ACKNOWLEDGEMENTS}

An earlier version of this paper was presented at the Instituto Welte's Sexto Simposio Bienal de Estudios Oaxaqueños in 2004. The authors gratefully acknowledge the organisers, as well as the research assistance of Laurel Smith, the artwork of Dick Gilbreath and the financial support provided by the National Science Foundation (SBE-GRS \# 0243295) under the grant, 'Transnational Networks of NGOs'. Errors remain the responsibility of the authors.

\section{REFERENCES}

Aguayo Quezada S. 1995. A Mexican milestone: seven NGOs form the civic alliance. Journal of Democracy 6: 157-167.

Barkin D. 1998. Wealth, Poverty, and Sustainable Development. Editorial JUS: Mexico City.

Bebbington A. 2004. NGOs and uneven development: geographies of development intervention. Progress in Human Geography 28: 725-745.

Bustamante JA. 1999. La migración indocumentada de Oaxaca a Estados Unidos de América de 1987 a 1998. In Coloquio Nacional Sobre Políticas Públicas de Atención al Migrante, Mancilla ZayasA (ed.). Gobierno Constitucional del Estado de Oaxaca: Oaxaca, Mexico.

Centro de Encuentros y Diálogos Interculturales (CEDI). 2001. Experiencias Organizativas de la Sociedad Civil en Oaxaca-Inventario Inicial. CEDI: Oaxaca, Mexico.

Clarke CG. 2000. Class, Ethnicity, and Community in Southern Mexico: Oaxaca's Peasantries. Oxford University Press: Oxford.

Cockcroft JD. 1998. Mexico's Hope: An Encounter with Politics and History. Monthly Review Press: New York.

Crewe E, Harrison E. 1999. Whose Development? An Ethnography of Aid. Zed Books: London.

Fernando J, Heston A (eds). 1997. The role of NGOs: charity and empowerment. Special edition (November), Annals of the American Academy of Political and Social Science 554: 8-210.

Foro de Organismos Civiles de Oaxaca (FOCO). 2000. Directorio de Organismos Civiles del Estado de Oaxaca. FOCO: Oaxaca, Mexico.

Josiah SJ. 2001. Approaches to expand NGO natural resource conservation outreach. Society and Natural Resources 14: 609-618.

Lewis D. 2001. The Management of Non-Governmental Organizations. Routledge: London.

Mawdsley E, Townsend J, Porter G, Oakley P. 2002. Knowledge, Power and Development Agendas: NGOs North and South. INTRAC: Oxford.

Morales Rodríguez C. (compilador) 1996. Organismos Civiles en el Estado de Oaxaca. Foro de Organismos Civiles de Oaxaca: Oaxaca, Mexico.

Peck J, Tickell A. 2002. Neoliberalizing space. Antipode 34: 380-404.

Roberts SM, Jones JP III, Fröhling O. 2005. NGOs and the globalization of managerialism: a framework for analysis. World Development 33: 1845-1864.

Sayer A. 1992. Method in Social Science, 2nd Edn. Routledge: London.

The Economist. 2000. The World in 2001. The Economist: London.

Townsend J, Mawdsley E, Porter G. 2002. Challenges for NGOs. In The Companion to Development Studies, DesaiV, PotterRB (eds). Arnold: London; 534-538.

Union of International Associations (UIA). 2003/4. Yearbook of International Organizations: Guide to Civil Society Networks. K.G. Saur Verlag: Munich.

United Nations Development Programme (UNDP). 2002. Human Development Report: Deepening Democracy in a Fragmented World. Oxford University Press: New York. 